\title{
Profil Pasien Tuberkulosis Anak dengan Anti-tuberculosis Drug Induced Hepatotoxicity di Rumah Sakit Umum Pusat Dr. Hasan Sadikin Bandung
}

Zara Safira, Sri Sudarwati, Anggraini Alam

Departemen Ilmu Kesehatan Anak Fakultas Kedokteran Universitas Padjadjaran/RSUP Dr. Hasan Sadikin, Bandung

Latar belakang. Dalam pengobatan tuberkulosis anak diperlukan kombinasi obat, seperti isoniazid, rifampisin, dan pirazinamid. Ketiga obat ini dapat menimbulkan efek samping berupa anti-tuberculosis drug induced hepatotoxicity (ADIH).

Tujuan. Penelitian ini bertujuan untuk mengetahui profil pasien tuberkulosis (TB) anak dengan ADIH.

Metode. Penelitian ini merupakan penelitian deskriptif kuantitatif potong lintang. Data diambil dengan metode total sampling dari rekam medis pasien TB anak yang mengalami gejala hepatotoksisitas dan telah menjalani pengobatan di RSUP Dr. Hasan Sadikin Bandung, dari Januari 2014-Mei 2017.

Hasil. Di antara 709 pasien TB anak di RSHS, 48 pasien mengalami ADIH. Enampuluh satu persen pasien berusia $\leq 5$ tahun, terdiri atas 15 laki-laki dan 21 perempuan, $24(67 \%)$ pasien mengalami gizi buruk. Duapuluh delapan pasien (78\%) mengalami ikterus, 17 (47\%) mengalami mual muntah, 24 (67\%) ditemukan hepatomegali. Peningkatan SGPT ditemukan pada 25 (69\%) pasien. Tujuhpuluh empat pasien mengalami peningkatan bilirubin $\geq 1 \mathrm{U} / \mathrm{L}$. Seluruh pasien ADIH dihentikan terapinya. Enampuluh tujuh persen kasus ADIH timbul di fase awal terapi obat anti tuberkulosis (OAT) dan 56\% pasien membaik selama 15-30 hari.

Kesimpulan. Gejala ADIH yang muncul pada anak berupa ikterus, mual dan muntah. Dari pemeriksaan fisik, sebagian besar mengalami hepatomegali. Pada pemeriksaan fungsi liver, terjadi peningkatan SGOT/SGPT dan bilirubin. Gejala ADIH kebanyakan muncul di fase awal terapi OAT. Sari Pediatri 2018;19(5):290-4

Kata kunci: anti-tuberculosis drug induced hepatotoxicity (ADIH), obat anti tuberkulosis (OAT), TB pada anak

\section{Pediatric Tuberculosis Patient's Profile with Anti-tuberculosis Drug Induced Hepatotoxicity in RSUP Dr. Hasan Sadikin Bandung}

Zara Safira, Sri Sudarwati, Anggraini Alam

Background. Combination therapy of Isoniazid, Rifampin, and Pyrazinamide required for the treatment of children tuberculosis. These drugs induced hepatotoxicity side effect or ADIH.

Objective. This research aims to discover $\mathrm{ADIH}$ in TB pediatric patients.

Methods. This research used quantitative descriptive cross-sectional study as method. Data was collected by total sampling method from the pediatric tuberculosis medical record showing hepatotoxic sign, treated in RSUP Dr. Hasan Sadikin Bandung, from January 2014 to May 2017.

Result. Of 709 patients, 48 were diagnosed with ADIH. Approximately $61 \%$ cases occurred in pediatric age $\leq 5$, consist of 15 males and 21 females. 24 of them (67\% patient), had malnutrition. 28 patients (78\%) were experiencing icterus, 17 (47\%) experiencing nausea and vomiting, and 24 (67\%) diagnosed with hepatomegaly. SGPT levels elevation occurred in 25 patients (69\%). Bilirubin elevation $\geq 1 \mathrm{U} / \mathrm{L}$ occurs in $74 \%$ patients. All patients got their treatment terminated. In $67 \%$ cases, ADIH occurred in early phase of therapy. 56\% of them improved in 15-30 days.

Conclusion. Signs of ADIH in pediatrics are icterus, nausea, and vomiting, while hepatomegaly appeared mostly in physical examination. In liver function test, SGOT/SGPT and bilirubin levels elevated. Those signs mostly occurred in early phase of therapy. Sari Pediatri 2018;19(5):290-4

Keywords: anti-tuberculosis drug induced hepatotoxicity (ADIH), anti-tuberculosis drug therapy, pediatric tuberculosis

Alamat korespondensi: Dr. Zara Shafira. Fakultas Kedokteran UNPAD Jl. Raya Bandung Sumedang Km. 21 Jatinangor Sumedang. Email: zarashafira@ gmail.com 
T uberkulosis merupakan penyakit infeksi menular penyebab kematian utama di dunia. Lembaga kesehatan dunia WHO memperkirakan pada tahun 2015 terdapat 10,4 juta kasus baru TB di dunia. Asia Tenggara menempati posisi pertama dengan angka kejadian $\mathrm{TB}$ tertinggi pada anak, yaitu 40\% dari kasus di tahun 2015. Indonesia termasuk dalam tiga negara dengan angka kejadian TB tertinggi di dunia, bersama India dan Cina. ${ }^{1}$

Saat ini, untuk pengobatan TB pada anak digunakan kategori 2(HRZ)/4(HR), terdiri atas kombinasi isoniazid, pirazinamid, dan rifampisin selama 2 bulan, dan dilanjutkan dengan kombinasi isoniazid dan rifampisin selama 4 bulan..$^{2-4}$ Obatobat ini berguna untuk mengeradikasi bakteri secara efektif. Namun, obat ini berpotensi menimbulkan efek samping. Terlebih lagi pada pasien anak yang fungsi organnya belum bekerja sempurna, efek samping obat sangat mungkin terjadi. ${ }^{5}$ Hepatotoksisitas merupakan efek samping paling banyak terjadi pada pemberian obat anti tuberkulosis (OAT) atau biasa disebuh dengan anti-tuberculosis drug induced hepatotoxicity (ADIH), 7\% dari semua efek samping disebabkan oleh OAT. ${ }^{6}$ Toksisitas akan meningkat ketika obat ini dikombinasikan. ${ }^{4}$ Isoniazid merupakan obat yang paling efektif dalam pengobatan TB. Sekitar $10 \%$ pasien yang mendapat isoniazid akan mengalami peningkatan aktivitas aspartat dan alanin transaminase di plasma. ${ }^{7}$ Selain itu, rifampisin juga dapat menyebabkan hepatotoksisitas. Kombinasi isoniazid dengan, rifampisin akan memicu metabolisme isoniazid sehingga akan terbentuk hidrazin yang lebih banyak. Pemberian dosis rifampisin lebih dari $15 \mathrm{mg} / \mathrm{kg}$ dapat memicu hepatotoksisitas pada anak. Pirazinamid juga dapat menimbulkan hepatotoksisitas dan biasanya muncul pada $15 \%$ pasien yang diberikan pirazinamid dengan dosis $40-50 \mathrm{mg} / \mathrm{kg}, 2-3 \%$ disertai dengan gejala kuning. ${ }^{8,9}$

Apa bila terjadi hepatotoksisitas disebabkan oleh obat tersebut maka pengobatan perlu dihentikan sampai gejala hepatotoksisitasnya tidak timbul kembali. Namun, penghentian obat ini akan berpengaruh pada keberhasilan pengobatan TB sehingga risiko terjadi perburukan penyakit TB, kambuh, dan resistensi obat menjadi lebih tinggi. ${ }^{10}$ Monitoring terhadap pemberian obat TB menjadi sangat penting, khususnya pada anak. Untuk melakukan monitoring pada anak diperlukan data epidemiologi, gejala klinis, keparahan, dan luaran.
Penelitian ini bertujuan untuk mengetahui profil pasien TB anak dengan anti-tuberculosis drug induced hepatotoxicity yang diharapkan dapat menjadi acuan untuk mendeteksi secara dini efek samping OAT pada pasien TB anak sehingga dapat dilakukan intervensi secara cepat dan tepat.

\section{Metode}

Penelitian observasional deskriptif kuantitatif dengan pendekatan potong lintang dilakukan dari bulan September 2016 - Juni 2017. Data diambil dengan metode total sampling dari rekam medis pasien TB anak. Kriteria inklusi adalah usia 1-14 tahun yang mengalami gejala hepatotoksisitas, dan telah menjalani pengobatan TB kategori anak di Rumah Sakit Umum Pusat Dr. Hasan Sadikin Bandung dari Januari 2014 - Mei 2017. Adapun kriteria eksklusi berupa data rekam medis yang tidak lengkap, pasien mengalami hepatitis akibat infeksi virus, atau pasien memakai obat hepatotoksik non-OAT.

Variabel penelitian ini meliputi karakteristik pasien (usia, jenis kelamin, status gizi), gambaran klinis yang timbul pada pasien, derajat hepatotoksisitas, waktu terjadinya hepatotoksisitas, dan waktu fungsi hati kembali normal. Gambaran klinis hepatotoksisitas yang dicatat berupa ikterus, hepatomegali, nyeri abdomen, mual, muntah, peningkatan bilirubin baik total maupun direk, dan peningkatan SGOT/SGPT pada pasien.

Pengumpulan data dilakukan setelah mendapat izin dari Komisi Etik Penelitian Kesehatan RSUP Dr. Hasan Sadikin Bandung. Data dianalisis dengan cara deskriptif, menghitung jumlah dan persentase, lalu disajikan dalam bentuk tabel untuk menggambarkan variabel yang diteliti.

\section{Hasil}

Didapatkan 48 pasien TB anak mengalami ADIH dari total keseluruhan pasien TB anak, yaitu 709 pasien sejak Januari 2014-Mei 2017. Tigapuluh enam data rekam medis yang memenuhi kriteria inklusi dan 12 data dieksklusi karena tidak lengkap sehingga tidak dapat dianalisis.

Rerata usia pasien $\mathrm{TB}$ anak yang mengalami $\mathrm{ADIH}$ adalah 5 tahun, dengan $61 \%$ berusia $\leq 5$ tahun. Pasien 
perempuan lebih banyak mengalami ADIH 19 (56\%) dibandingkan dengan laki-laki 15 (44\%). Kebanyakan pasien TB anak yang mengalami ADIH memiliki status gizi buruk, 24 (67\%) pasien. Tercatat, sekitar 5 pasien didiagnosis marasmus.

Gejala ikterus muncul pada 28 pasien ADIH dengan menampakkan adanya perubahan warna menjadi kuning pada kulit atau sklera mata. Selain ikterus ditemukan hepatomegali pada 24 pasien, sedangkan 12 pasien lagi tidak mengalami hepatomegali. Tujuhbelas pasien mengalami mual dan muntah dan 1 pasien mengeluh nyeri abdomen (Tabel 2).

Berdasarkan pemeriksaan laboratorium, 25 (74\%) pasien mengalami peningkatan bilirubin total dan 32 (94\%) pasien mengalami peningkatan bilirubin direk. Kenaikan SGOT dialami oleh 28 pasien dan kenaikan SGPT 25 pasien. Enampuluh empat persen pasien ADIH didiagnosis TB paru dan 36\% TB ekstra paru.

Berdasarkan derajat hepatotoksisitas (Tabel 3) didapatkan hasil 18 orang pasien mengalami hepatotoksisitas ringan derajat 1 , ditandai dengan peningkatan SGPT <2,5 kali ULN. Dua orang pasien mengalami hepatotoksisitas ringan derajat 2 dengan kenaikan SGPT 2,5-5 kali ULN, 7 pasien mengalami hepatotoksisitas sedang derajat 3 dengan kenaikan SGPT antara 5-10 kali ULN, dan 3 orang pasien mengalami hepatotoksisitas berat dengan kenaikan SGPT $>10$ kali ULN. Sementara itu, 6 orang pasien tidak mengalami kenaikan SGOT dan SGPT.

Dari jenis OAT yang diminum oleh pasien, semua pasien menggunakan OAT kategori anak yaitu

Tabel 1. Profil umum pasien yang diteliti

\begin{tabular}{llcc}
\hline Karakteristik & & $\begin{array}{c}\text { Jumlah } \\
\mathrm{n}=36\end{array}$ & $\%$ \\
\hline Usia (tahun) & & 22 & 61 \\
& $\leq 5$ & 3 & 8 \\
& $5-10$ & 11 & 31 \\
Jenis kelamin & & & \\
& Laki-laki & 15 & 42 \\
& Perempuan & 21 & 58 \\
Status gizi & & & \\
& Buruk & 24 & 67 \\
& Kurang & 4 & 11 \\
& Normal & 8 & 22 \\
\hline
\end{tabular}

Tabel 2. Gambaran klinis

\begin{tabular}{|c|c|c|c|}
\hline Gambaran klinis & & $\begin{array}{c}\text { Jumlah } \\
\mathrm{n}=36\end{array}$ & $\%$ \\
\hline \multicolumn{4}{|l|}{ Ikterus } \\
\hline & Ya & 28 & 78 \\
\hline & Tidak & 8 & 22 \\
\hline \multicolumn{4}{|l|}{ Hepatomegali } \\
\hline & Ya & 24 & 67 \\
\hline & Tidak & 12 & 33 \\
\hline \multicolumn{4}{|l|}{ Nyeri abdomen } \\
\hline & Ya & 1 & 3 \\
\hline & Tidak & 35 & 97 \\
\hline \multicolumn{4}{|l|}{ Mual muntah } \\
\hline & Ya & 17 & 47 \\
\hline & Tidak & 19 & 53 \\
\hline \multicolumn{4}{|l|}{ Bilirubin (U/L) } \\
\hline \multicolumn{4}{|l|}{ Total } \\
\hline & $<1$ & 9 & 26 \\
\hline & $\geq 1$ & 25 & 74 \\
\hline \multicolumn{4}{|l|}{ Direk } \\
\hline & $<0,3$ & 2 & 6 \\
\hline & $\geq 0,3$ & 32 & 94 \\
\hline \multicolumn{4}{|l|}{ SGOT (U/L) } \\
\hline & $<51$ & 8 & 22 \\
\hline & $\geq 51$ & 28 & 78 \\
\hline \multicolumn{4}{|l|}{ SGPT (U/L) } \\
\hline & $<39$ & 11 & 31 \\
\hline & $\geq 39$ & 25 & 69 \\
\hline
\end{tabular}

Keterangan: $\mathrm{U} / \mathrm{L}=$ units per liter, $\mathrm{SGOT}=$ serum glutamic oxaloacetic transaminase, $\mathrm{SGPT}=$ serum glutamic pyruvic transaminase

Tabel 3. Derajat hepatotoksisitas

\begin{tabular}{|c|c|c|c|}
\hline Derajat & & $\begin{array}{c}\text { Jumlah } \\
\mathrm{n}=36\end{array}$ & $\%$ \\
\hline Normal & & 6 & 17 \\
\hline 1(ringan) & $\begin{array}{l}<2,5 \times \text { ULN (SGPT 51-125 } \\
\text { U/L) }\end{array}$ & 18 & 50 \\
\hline 2 (ringan) & $\begin{array}{l}2,5-5 \times \text { x ULN (SGPT 126-250 } \\
\text { U/L) }\end{array}$ & 2 & 6 \\
\hline 3 (sedang) & $\begin{array}{l}5-10 \times \text { ULN (SGPT 251-500 } \\
\text { U/L) }\end{array}$ & 7 & 19 \\
\hline 4 (berat) & $>10 \times$ ULN $(\mathrm{SGPT}>500 \mathrm{U} / \mathrm{L})$ & 3 & 8 \\
\hline
\end{tabular}


2(HRZ)/4(HR), menggunakan kombinasi isoniazid, pirazinamid, dan rifampisin selama 2 bulan, kemudian dilanjutkan dengan kombinasi isoniazid dan rifampisin selama 4 bulan. Berdasarkan pengamatan didapatkan 27 (75\%) pasien menggunakan kombinasi OAT lepasan dan 9 (25\%) menggunakan OAT tablet kombinasi dosis tepat. Waktu kejadian tertera pada Tabel 4,

Tabel 4. Waktu kejadian hepatotoksisitas

\begin{tabular}{lcc}
\hline Waktu (minggu) & $\begin{array}{c}\text { Jumlah } \\
\mathrm{n}=36\end{array}$ & $\%$ \\
\hline $0-2$ & 9 & 25 \\
$2-4$ & 15 & 42 \\
$4-8$ & 5 & 14 \\
\hline$>8$ & 7 & 19 \\
\hline
\end{tabular}

Kejadian ADIH paling banyak pada 2-4 minggu pengonsumsian OAT, yaitu sekitar 15 (42\%) pasien. Sembilan $(25 \%)$ pasien muncul DIH pada terapi obat minggu ke-2, 5 (14\%) pasien pada terapi obat minggu ke- 4 sampai 8, dan 7 (19\%) pasien mengalami DIH pada pengonsumsian OAT lebih dari 8 minggu. Pengonsumsian OAT dihentikan pada 29 (81\%) untuk penanganan DIH, lalu mulai direintroduksi kembali dengan OAT. Tujuh (19\%) pasien juga mengalami penggantian OAT dengan streptomisin dan etambutol. Pasien dengan penggantian OAT kebanyakan adalah pasien dengan TB berat.

Duapuluh 20 (56\%) pasien mengalami perbaikan setelah menjalani terapi $15-30$ hari, 8 (22\%) pasien menjalani terapi $<15$ hari, dan $8(22 \%)$ pasien menjalani terapi $>30$ hari. Berdasarkan hasil pengamatan, rentang waktu perbaikan yang dialami pasien sekitar 2-67 hari.

\section{Pembahasan}

Berdasarkan hasil pengamatan didapatkan pasien TB anak yang mengalami ADIH di RSUP Dr. Hasan Sadikin Bandung dari Januari 2014 - Mei 2017 sejumlah 48 orang dari total keseluruhan 709 pasien TB anak. Donald ${ }^{11}$ melaporkan bahwa sekitar 10\% pasien TB anak mengalami ADIH, ditandai dengan adanya peningkatan pada serum transaminase.

Terjadinya TB pada anak tidak terlepas dari faktor yang memengaruhinya. Pada penelitian ini didapatkan data bahwa kebanyakan pasien TB anak yang mengalami ADIH berusia berkisar $\leq 5$ tahun, (61\%). Rusmawati ${ }^{12}$ melaporkan $55,2 \%$ pasien TB anak yang mengalami ADIH berusia 1-5 tahun. Untuk itu, pemberian OAT pada anak usia 1-5 tahun perlu pengawasan yang ketat. Tidak terdapat perbedaan yang cukup signifikan antara laki-laki dan perempuan, tetapi jumlah perempuan lebih banyak dibandingkan dengan laki-laki. Penelitian sebelumnya melaporkan bahwa perempuan lebih berisiko untuk terkena ADIH dibandingkan dengan laki-laki. ${ }^{6,9}$ Bila dilihat berdasarkan status gizi pasien, $67 \%$ pasien mengalami gizi buruk. Menurut Rusmawati. ${ }^{12}$ terdapat hubungan antara gizi buruk dan terjadinya ADIH terutama pada anak usia $<14$ tahun yang mendapat terapi OAT.

Gejala klinis yang sering timbul pada pasien TB anak di penelitian ini adalah adanya ikterus, mual, dan muntah. Berdasarkan pemeriksaan fisik didapatkan adanya pembesaran pada liver. Dicurigai sebagai kerusakan awal pada liver sehingga perlu diberikan penanganan lebih cepat agar tidak terjadi perburukan. Berdasarkan pemeriksaan fungsi liver didapat 78\% pasien mengalami peningkatan SGOT dan 69\% mengalami peningkatan SGPT. Separuh pasien mengalami hepatotoksisitas ringan derajat 1 dengan peningkatan SGPT kurang dari 2,5 kali. Peningkatan serum bilirubin terjadi pada $94 \%$ pasien. Peningkatan SGOT dan SGPT hampir dialami oleh sebagian besar pasien ADIH anak. Donald ${ }^{11}$ melaporkan bahwa sekitar 9,9\% pasien ADIH anak mengalami peningkatan SGOT dan SGPT dan hanya 0,22\% yang menampakkan adanya kuning. Hal tersebut berbeda dengan kondisi pasien dalam penelitian ini karena $78 \%$ pasien mengeluhkan adanya ikterus pada tubuh, gejala paling banyak terjadi dibandingkan gejala ADIH lainnya.

Sebagian besar pasien TB anak mengalami ADIH pada fase inisial terapi atau 2 bulan pertama terapi. Empatpuluh dua persen kasus terjadi pada minggu ke- 2 sampai 4 dan $25 \%$ terjadi sebelum minggu ke- 2 . Kemunculan ADIH biasa terjadi pada 2 bulan pertama tahap awal pengobatan dan paling banyak pada dua minggu pertama setelah diberikan terapi OAT. ${ }^{6,7,9,14}$ Baghei $\mathrm{dkk}^{6}$ mengatakan bahwa hepatotoksisitas akibat OAT akan berkembang di 2 minggu pertama setelah pemberian OAT. Kondisi tersebut dapat dijadikan acuan dalam memberi OAT pada pasien anak dan pemantauan terhadap respon obat pada pasien TB anak. Pasien TB anak yang menjalani pengobatan 
pada tahap awal perlu mendapat pengawasan ketat untuk mencegah terjadinya efek samping OAT atau untuk deteksi lebih dini terhadap efek samping yang ditimbulkan sehingga mencegah komplikasi yang akan terjadi.

Lebih dari separuh pasien (56\%) mengalami perbaikan setelah mendapatkan penanganan $\mathrm{ADIH}$ selama 15-30 hari. Rifai dkk ${ }^{10}$ melaporkan pada pasien ADIH dewasa terdapat $64 \%$ mengalami perbaikan kurang dari 15 hari. Berdasarkan American College of Gastroenterology (ACG) Clinical Guideline, pedoman untuk diagnosis dan terapi $\mathrm{ADIH}$ menyebutkan jika kondisi pasien tidak mengalami perbaikan dalam 30 hari maka prognosisnya buruk. ${ }^{14}$

Keterbatasan yang dihadapi dalam penelitian ini, yaitu pasien ADIH anak yang masih sangat jarang sehingga sampel yang diperoleh juga sedikit. Selain itu, masih terdapat kekeliruan dalam pencatatan di rekam medis dan pemeriksaan laboratorium kadang tidak dilampirkan pada rekam medis pasien sehingga menghambat dalam proses pengambilan dan analisis data. Disarankan penelitian lebih lanjut mengenai hubungan gambaran klinis $\mathrm{ADIH}$ dan faktor risikonya. Rekam medis pemeriksaan yang dilakukan oleh pasien hendaknya tersimpan dengan baik untuk memudahkan dokter dalam penegakan diagnosis, ataupun jika sewaktu data diperlukan untuk penelitian.

\section{Kesimpulan}

Disimpulkan bahwa gejala ADIH yang sering muncul pada anak berupa ikterus, mual, dan muntah. Berdasarkan pemeriksaan fisik, sebagian besar mengalami hepatomegali. Pada pemeriksaan fungsi liver, terjadi peningkatan SGOT/SGPT dan bilirubin. Gejala ADIH paling sering muncul di dua bulan pertama terapi OAT.

\section{Daftar pustaka}

1. World Health Organization. Global tuberculosis report 2016: World Health Organization. Geneva: WHO; 2016.
2. World Health Organization. Guidance for National Tuberculosis Programmes on the Management of Tuberculosis in Children 2014. Geneva: WHO; 2014.

3. Kementerian Kesehatan RI. Pedoman Nasional Pengendalian Tuberkulosis. Jakarta: Kementrian Kesehatan RI; 2014.

4. Roy B, Chowdhury A, Kundu S, Santra A, Dey B, Chakraborty $M$, dkk. Increased risk of antituberculosis drug-induced hepatotoxicity in individuals with glutathione S-transferase M1 'null'mutation. J Gastroenterol Hepatol 2001;16:1033-7.

5. Sari ID, Yuniar Y, Syaripuddin M. Studi monitoring efek samping obat antituberkulosis Fdc kategori 1 di Provinsi Banten dan Provinsi Jawa Barat. Media Penelitian dan Pengembangan Kesehatan 2014;24:28-35.

6. Baghaei P, Tabarsi P, Chitsaz E, Saleh M, Marjani M, Shemirani $\mathrm{S}$, dkk. Incidence, clinical and epidemiological risk factors, and outcome of drug-induced hepatitis due to antituberculous agents in new tuberculosis cases. Am J Ther 2010;17:17-22.

7. Malani PN. Harrison's Principles of Internal Medicine. JAMA 2012;308:1813-4.

8. Bruton LL, Lazo JS, Parker KL. Goodman and Gilman's the pharmacological basis of therapeutical. New York: McGrawHill; 2006.

9. Tostmann A, Boeree MJ, Aarnoutse RE, De Lange W, Van Der Ven AJAM, Dekhuijzen R. Antituberculosis drug induced hepatotoxicity: concise up to date review. J Gastroenterol Hepatol 2008;23:192-202.

10. Rifai A, Herlianto B, Mustika S, Pratomo B, Supriono S. Insiden dan gambaran klinis hepatitis akibat obat anti tuberkulosis di Rumah Sakit Umum Daerah Dr. Saiful Anwar Malang. J Kedokt Brawijaya 2015;28:238-41.

11. Donald PR. Antituberculosis drug-induced hepatotoxicity in children. Pediatric Reports 2011;3:16.

12. Rusmawati, Ismail D, Naning R. Gizi kurang sebagai faktor risiko hepatitis drug induced karena obat anti tuberkulosis. J Biomedika 2009;1:45-9.

13. Sumantri AF, Djumhana A, Wisaksana R, Sumantri R. Insidensi dan karakteristik hepatotoksisitas obat antituberkulosis pada penderita tuberkulosis dengan dan tanpa infeksi HIV. Global Medical \& Health Communication (GMHC) 2015;3:78-82.

14. Chalasani NP, Hayashi PH, Bonkovsky HL, Navarro VJ, Lee WM, Fontana RJ. ACG clinical guideline: the diagnosis and management of idiosyncratic drug-induced liver injury. Am J Gastroenterol 2014;109:950-66. 